\title{
Penggunaan Serai Wangi (Andropogon nardus L.) sebagai Insektisida Nabati pada Tegakan Tusam (Pinus merkusii Jung Et De Vriese)
}

\author{
Serai Wangi (Andropogon nardus L.) as Original Insecticide on Pine Tree (Pinus Jung Et De \\ Vriese)
}

\section{Fransina Latumahina}

Jurusan Kehutanan, Fakultas Pertanian, Universitas Pattimura Ambon

E-mail:fransina_latumahina@yahoo.com

\begin{abstract}
Termites can disrupt the growth of Pine (Pinus merkusii Jung Et De Vriese), it may affect to the function and role of the forest area. To minimize the losses caused by Termite (Mactotermes gilvus Hagen) precautions and control must be carried out effectively and efficiently. The use of insecticide plant Serai Wangi (Cymbopogon nardus $L$.) can reduce pest populations until $90 \%$. The purposes of this study are determining the intensity of damage and the widespread attacks Termite and also the application on mortality subterranean termites which attack Pine (Pinus Jung Et De Vriese) in protected forest Nona Mountain Ambon. Fieldwork was conducted in four blocks on 100 trees. The results shows that the intensity of attacks on termites ranged from $\mathbf{2 5 . 3 5 \%}$ until to $\mathbf{5 4 . 1 8 \%}$. The application of Serai Wangi on subterranean termites in the field and laboratory have same results. The highest mortality occurred in two weeks on $5 \%$ concentration.
\end{abstract}

Keywords: Serai wangi, termite, original insecticides, forest protection

\section{Abstrak}

Serangan Rayap tanah mampu menganggu pertumbuhan tegakan Tusam (Pinus merkusii Jung Et De Vriese) yang dapat mempengaruhi fungsi dan peran kawasan hutan. Untuk meminimalisir kerugian yang disebabkan oleh hama Rayap Tanah (Mactotermes gilvus Hagen) maka tindakan pencegahan maupun pengendalian harus dilakukan secara efektif dan efisien. Penggunaan insektisida nabati dari tanaman Sereh Wangi (Cymbopogon nardus L) mampu menurunkan populasi hama hingga $90 \%$. Tujuan penelitian ini untuk mengetahui intensitas kerusakan dan luas serangan Rayap Tanah pada tegakan Tusam dan aplikasi ekstrak Serai wangi terhadap mortalitas rayap tanah yang menyerang tanaman Tusam (Pinus merkusii Jung Et De Vriese) dalam kawasan Hutan Lindung Gunung Nona Ambon. Penelitian lapangan dilakukan pada 4 blok pengamatan dengan 100 pohon. Hasil penelitian menemukan bahwa intensitas serangan pada 4 blok pengamatan berkisar dari $25,35 \%$ hingga $54,18 \%$. Aplikasi insektisida Serai Wangi pada rayap tanah di lapangan dan di laboratorium menunjukan hasil yang sama yakni mortalitas tertinggi terjadi pada minggu ke-2 dengan konsentrasi sebesar $5 \%$.

Kata kunci: Serai wangi, rayap tanah, insektisida nabati, hutan lindung 